\title{
OBTAINING AND ESTIMATING THE POTENTIAL OF PROTEIN NUTRACEUTICALS FROM HIGHLY MINERALIZED COLLAGEN-CONTAINING BEEF RAW MATERIALS
}

\author{
Natalia Yu. Mezenova ${ }^{1}$, Svetlana V. Agafonova ${ }^{1}$, Olga Ya. Mezenova ${ }^{1 *}$, Larisa S. Baidalinova ${ }^{1}$, Thomas Grimm ${ }^{2}$ \\ ${ }^{1}$ Kaliningrad State Technical University, Kaliningrad, Russia \\ ${ }^{2}$ Biotechnology company ANiMOX, Berlin, Germany
}

\begin{abstract}
Keywords: bovine bone, molecular weight, degree of hydrolysis, high-temperature, animal tissue, proteins, nutraceuticals
Abstract

Highly mineralized collagen-containing beef raw materials (tibia, fibula and costal bones) are a source of valuable protein nutraceuticals. They include high molecular weight proteins, oligopeptides and amino acids, which anabolic and physiological potential is used insufficiently. Protein nutraceuticals were obtained by high-temperature hydrolysis of beef raw materials in combination with enzymolysis by proteolytic enzyme preparations Alcalase 2,5 L, Protamex, Protosubtilin G3x. The water-soluble fraction of hydrolysates was studied after its separation and freeze-drying on the content of nitrogenous compounds, fats, minerals, formol-titrated nitrogen, fractional molecular composition. The mathematical dependencies of accumulation of low molecular weight products of protein hydrolysis on enzymolysis duration and doses of different enzyme preparations were obtained. The rational technological scheme of complex processing of beef raw materials with production of protein, fat and mineral-protein additives was proposed. The protein weight fraction in the freeze-dried protein hydrolysates was 69.5-89.6\%. All studied protein additives contained peptides with a molecular weight of not more than $100 \mathrm{kDa}$. The content of low-molecular weight oligopeptides with a molecular weight of less than $10 \mathrm{kDa}$ in the protein additives obtained by enzymatic thermal hydrolysis was more than $90 \%$. The amino acid composition of protein additives produced by different hydrolytic methods was analyzed. Sensory and functional-technological properties of freeze-dried protein compositions were studied. The amino acid potential, high assimilability and physiological activity of protein nutraceuticals from collagen-containing beef raw materials were established. It is recommended to use them in the composition of specialized biologically active additives (BAAs) to food of the osteotropic direction in recipes of specialized and personalized products as a source of amino acids and active peptides.

\section{Funding:}

The study was supported by the grant of the Foundation for Assistance to Small Innovative Enterprises (FASIE) (Program "START-1"), Research and Development theme: "Development of the technology for processing secondary meat and bone raw materials and producing experimental samples of functional components of protein, lipid and protein-mineral compositions (Contract № 3209ГC1/48676 of 03.09.2019, Registration No.AAAA-A19-119101790069-4)
\end{abstract}

\section{Introduction}

The Russian meat industry produces about one million tons of secondary meat and bone raw materials annually. About $20 \%$ of this amount is industrially processed, while bone waste is practically not used for production of valueadded products. ${ }^{1}$. Today, more than 150 enterprises have been working in the Kaliningrad region in the sphere of beef husbandry accumulating from 20 to $50 \%$ of secondary material weight (bones, skin, viscera), which use is also problematic. The most acute problem is the processing of cattle bone raw materials characterized by an increased content of highly mineralized collagen tissues (tibia, fibula and costal bones). This raw material is often utilized by different methods including incineration causing ecological damage to nature ${ }^{2}$.

An increased use of the potential of collagen-containing waste from meat raw material processing is a topical task

\footnotetext{
${ }^{1}$ Kravchenko V. Meat market in Russia: results of 2019 and prospects. Meat and by-products, press-releases. Retrieved from https://specagro.ru/ news/202003/rynok-myasa-v-rossii-itogi-2019-g-i-perspektivy Accessed January 30, 2021. (In Russian)

${ }^{2}$ Kaliningrad region in figures. 2020: Brief statistical digest / Kaliningradstat-Kaliningrad, $2020-142 \mathrm{p}$. Retrieved from https://kaliningrad.gks.ru/ storage/mediabank/2020(\%D0\%BA\%D1\%80\%D0\%B0\%D1\%82\%D0\%BA\%D 0\%B8\%D0\%B9)(1).pdf) Accessed January 20, 2021. (In Russian)
}

in many slaughterhouses, poultry factories and enterprises of processing and food industries of many countries in the world [1,2]. The experience in the processing of collagen-containing waste from poultry factories shows that feeding meal and different additives, nitrogen-containing media for microbial biotechnology, organic fertilizers, polymer compositions for textile production, collagen dispersions used in feed and food industries are produced today from poultry feather raw materials $[3,4,5,6,7]$. A rational way for solving the problem of using fish bone raw materials including those that are unacceptable for feeding purposes (scales, smoked fish heads) is producing food additives of the protein, fat and proteinmineral composition by deep hydrolysis $[8,9]$. Today, highly mineralized meat and bone raw materials (waste from cattle processing), which differ from poultry and fish waste by the increased strength and specific amino acid composition of collagen proteins, are mainly used for animal feed [10].

It is important that all types of collagen-containing animal raw materials are a valuable source of natural proteins, amino acids, lipids, macro- and microelements, nucleic materials and other natural biologically active substances (BASs). Isolation of these BAAs and the fullest use of their potential for humans are an aim of many scientific stud- 
ies. At present, many scientific developments suggest using the products of secondary raw material processing in the food technology as food additives and BAAs to food, in the composition of multicomponent premixes, protein concentrates $[1,2,3,4,5,6,7,8,9,10]$. Protein compositions obtained by deep hydrolysis of bone and meat raw materials are constituents of pharmacological compositions, microbiological media, constructive tensides [11,12]. It is promising to use a potential of collagen-containing resources in aquaculture as sources of amino acid and fatty nutrition [10]. It is important that nowadays domestic feedstuff for industrial fish production is critically deficient and this is the main problem in the development of domestic fish farming [13]. Today, many farming enterprises engaged in poultry and pig breeding suffer from a deficiency of the highly assimilable natural protein feedstuff. The task of using the potential of collagen-containing raw materials in the food industry is not less important. With guaranteed food safety and proved biological effectiveness of recovered biologically active substances, it seems expedient and rational to use them in a composition of new generation products - specialized and functional products intended for strengthening the locomotor system of the body, in sports nutrition, gerodietetic products, curative nutrition for patients suffering from collagenosis and so on $[14,15,16]$.

Recovery of valuable organic components from secondary meat and bone raw materials is based on their destruction, which is performed by different methods. The main methods for degradation of highly mineralized raw materials are based on tough hydrolysis, which is carried out using chemical reagents (acids, alkali) as well as by enzymatic, thermal or combined ways $[2,17,18,19,20,21,22,23]$. However, acids and alkali destroy several valuable amino acids, reduce the biological value of proteins and peptides, hydrolyse lipids. With that, the process is accompanied by formation of salts and chemical pollution of effluents, excludes the use of other fractions of organic raw materials (lipids, minerals) for food purposes [12,18,22].

It is also necessary to note that the investigated enzymatic methods for protein production from meat and bone raw materials are not effective enough for industrial use of end products of hydrolysis in food systems $[17,18,19]$. It was established that enzymatic hydrolysates of animal raw material waste often contain emulsion-type protein-fat mixtures, which are often suitable only as a biodiesel fuel, as well as in the composition of feedstuff for animals, fertilizers for soil, as a carbohydrate and nitrogen source for microbial synthesis. The latter is promising for the development of industrial microbial biotechnology, since a complex process that includes enzymatic biodegradation of waste and production of enzymes at a single stage is possible in this case $[1,2,10,13]$. It should be noted that today even the most active proteolytic enzymes with the collagenase activity hydrolyze strong framework structures of meat and bone raw materials only by $30-40 \%$; then, the process attenuates. With that, in its entirety, the process is characterized by long duration, a necessity to inhibit enzymes and often is accompanied by formation of non-protein components that cause unpleasant odor and increased microbial contamination, which excludes using end products of hydrolysis for food purposes [21]. Another problem of enzymolysis is a necessity to take into account specificity, activity and also costs of enzymes, which price is steadily rising in the modern market [13].

Despite available scientific technological developments, the question of the full and effective use of the biological potential of meat and bone raw materials has no economically efficient solution up to now. Proposed processing methods allow recovering the most valuable protein fraction from different collagen raw materials at a level of 50$60 \%$ of the weight of contained protein; with that, the complex and non-waste processing is not achieved [13,21,23].

To solve the problem of the complex and rational use of secondary meat and bone raw materials and to increase sustainability of meat processing productions, it is expedient to use modern biotechnologies that allow processing raw materials using the principles of their deep molecular conversion based on combination of enzymatic and thermal destruction. This principle of raw material processing positively showed itself in comparative investigations of different methods for destruction of mineralized collagen-containing fish scales [8]. The method is based on the preliminary action of specific proteolytic enzymes of new generation on raw materials with the following high temperature processing. This allows deep destruction of highly mineralized protein components (collagen, elastin, reticulin), hydrolysis of connective tissues liberating all organic fractions including fatty and mineral [9]. With that, valuable amino acids of protein fractions are preserved, including essential (lysine, valine, tryptophan, cystine, cysteine and others), as well as amino acids of the osteotropic action (proline, oxyproline, glycine, alanine); high molecular weight complexes are destroyed with formation of proteinmineral compositions (calcium, phosphorous, magnesium, potassium). The following recovery and purification of each fraction enable their use as natural food and feed additives. Finally, it is possible to obtain three compositions of natural biologically active components (protein, fatty and mineral-protein) with the high physiological potential from problematic meat and bone raw materials.

The most important fraction produced by combined hydrolysis of meat and bone raw materials is the protein fraction, which according to its potential can be assigned to natural functional nutriceuticals having the biological activity and required by the body, first of all, for the anabolic and energy purposes. Deep enzymatic thermal hydrolysis enables obtaining low molecular weight peptides $(1-100 \mathrm{kDa})$ from collagen-containing animal tissues. The most valuable is the fraction with a molecular weight of $1-10 \mathrm{kDa}$, which is assigned to the so-called active peptides and comprises di-, tri-, and tetra-peptides with novel physiological properties [23]. It was established that low molecular weight peptides of animal origin are effective antioxidants, antiseptics, have the immunomodulatory, hypotensive, regenerative, reproductive activities, exert the 
cytotoxic effect on several cancer cell lines, inhibit angiotensin-converting enzymes [11,12,25,26,27].

The valuable protein potential of collagen tissues from meat and bone raw materials and their use in food technologies were confirmed by results of multiple studies $[1,2,10,11$ $, 13,14,17,18,19,20,22,27]$. Low molecular weight products of collagen protein destruction are a promising bio-material for food, pharmaceutical, medical, microbiological, feed industries as they have increased assimilability and can influence effectiveness of many biological processes. It was proved that di- and tri-peptides with the amino acid sequence -Pro-Hyp- and -Pro-Hyp-Gly- have notable stimulating ability of collagen synthesis, which is important for wound healing processes $[11,12,25,26,27]$. It is important that oral and enteric consumption of collagen peptides favorably affect joints, rate of wound and ulcer healing $[1,26]$. When consuming peptides of collagen origin, patients with joint degenerative diseases showed the growth in the mineral density of bone tissues [27]. It was established that food with "collagen pieces" improves the structure and composition of hair and fingernails, facilitates an increase in the size of collagen fibrils in the Achilles tendons, induces the strength of fibroblasts and collagen fibrils in derma of human skin [1].

To recover and use proteins from highly mineralized collagen-containing beef raw material, it is necessary to take into consideration peculiarities of its composition, namely, high structural strength conditioned by the high content of calcium and the procollagen form of proteins. For tissue degradation, therefore, it is topical to use high temperature hydrolysis in the aqueous medium carried out at elevated pressure and with the preliminary action of specific proteolytic enzymes (endo- and exopeptidases). This method of hydrolysis proved its effectiveness in processing highly mineralized fish heads, scales and backbones that are accumulated in fish canning enterprises as waste $[8,9]$.

The aim of the work was production of protein components from highly mineralized beef meat and bone raw materials by the extraction hydrolytic method with enzymatic thermal hydrolysis and assessment of their potential for using as food and biologically active additives - protein nutriceuticals.

The main tasks of the study were to substantiate rational regimes for deep hydrolysis of beef tibia, fibula and costal bones for obtaining protein products and determine their targeted quality indicators that suggest their biological and physiological value, functionality and processability.

\section{Objects and methods}

The experiments were carried out in the Center for Advanced Technologies of Protein Use of the Department of Food Biotechnology of the Kaliningrad State Technical University.

Beef tibia and fibula with heads provided by the Golubevsky meat processing plant "LEAR" and beef costal bones from the slaughterhouse in the Dobroye settlement (Kaliningrad region) were used as raw materials.

Proteolytic enzyme preparations with the collagenase activity Alcalase 2,5 L and Protamex (Novozymes, Den- mark), Protosubtilin G3x and pancreatin (Sibbiopharm Ltd., Russia) were used for enzymolysis.

The generally accepted, traditional, standard and authors' methods were used in the experiments. The protein content was determined by GOST 25011-2017 ${ }^{3}$, fat by GOST 23042-2015', ash by GOST 31727-2012

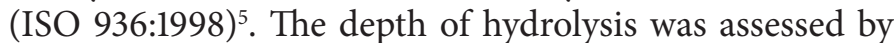
accumulation of formol-titrated nitrogen (FTN) or aminoammonia nitrogen (AAN) according to GOST R55479$2013^{6}$. The amino acid content was determined by GOST

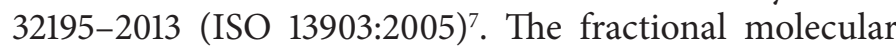
composition of peptides was determined by the methods of high performance liquid chromatography (HPLC) using an exclusion chromatographic column Yarra from Phenomenex (Yarra 3u SEC-2000).

When grinding, hard meat and bone raw materials were restructured step-by-step. Initially, a press was used, which crushed bones into $20-50 \mathrm{~mm}$ size pieces. Then, this mass was transformed into ground mixtures consisted of 3-5 $\mathrm{mm}$ size particles in special containers using the "rotating knife" method.

In the experiments on hydrolysis, $100 \mathrm{~g}$ of ground raw materials were initially placed into hermetical glass jars with lids, mixed in warmed water in a ratio of $1: 1$ by weight at a temperature of $50-55^{\circ} \mathrm{C}$. Then, the samples were introduced into a shaking apparatus for enzymolysis during a preset time period. After the end of enzymolysis, recovered fat was removed adding hot water into the ground mass. After holding for $30 \mathrm{~min}$., fat was separated by centrifugation. Thermal hydrolysis of the fermented mass was carried out in a thermal reactor with a rotating mixer at a temperature of $130-160^{\circ} \mathrm{C}$ within the mass for one hour; then, the content was cooled and fractionated by centrifugation. After centrifugation, three fractions were obtained - fatty (upper), water soluble (medium) and mineral-protein (sedimentary, lower). The complex scheme of processing highly mineralized collagen-containing beef raw materials with production of protein nutraceuticals and accompanying fatty and protein-mineral additives is presented in Figure 1.

The water soluble protein fraction, which was freezedried with preliminary thickening by the vacuum evaporation method, was analyzed.

\section{Results and discussion}

Initially, the most effective enzyme preparation and rational regimes of its use for enzymolysis of meat and bone raw materials were selected. This would allow maximum transformation of highly mineralized high molecular

${ }^{3}$ GOST 25011-2017 "Meat and meat products. Protein determination methods". Moscow: Standartinform, 2018. - 14 p. (In Russian)

${ }^{4}$ GOST 23042-2015 "Meat and meat products. Methods of fat determination”. Moscow: Standartinform, 2019. - 8 p. (In Russian)

${ }^{5}$ GOST 31727-2012 (ISO 936:1998) "Meat and meat products. Determination of total ash”. Moscow: Standartinform, 2019. - 11 p. (In Russian)

${ }^{6}$ GOST R 55479-2013 "Meat and meat products. Method for determination of amino-ammonia nitrogen”. Moscow: Standartinform, 2019. - 8 p. (In Russian)

${ }^{7}$ GOST 32195-2013(ISO 13903:2005) "Feeds, compound feeds. Method for determination of amino acids". Moscow: Standartinform, 2020. — 23 p. (In Russian) 


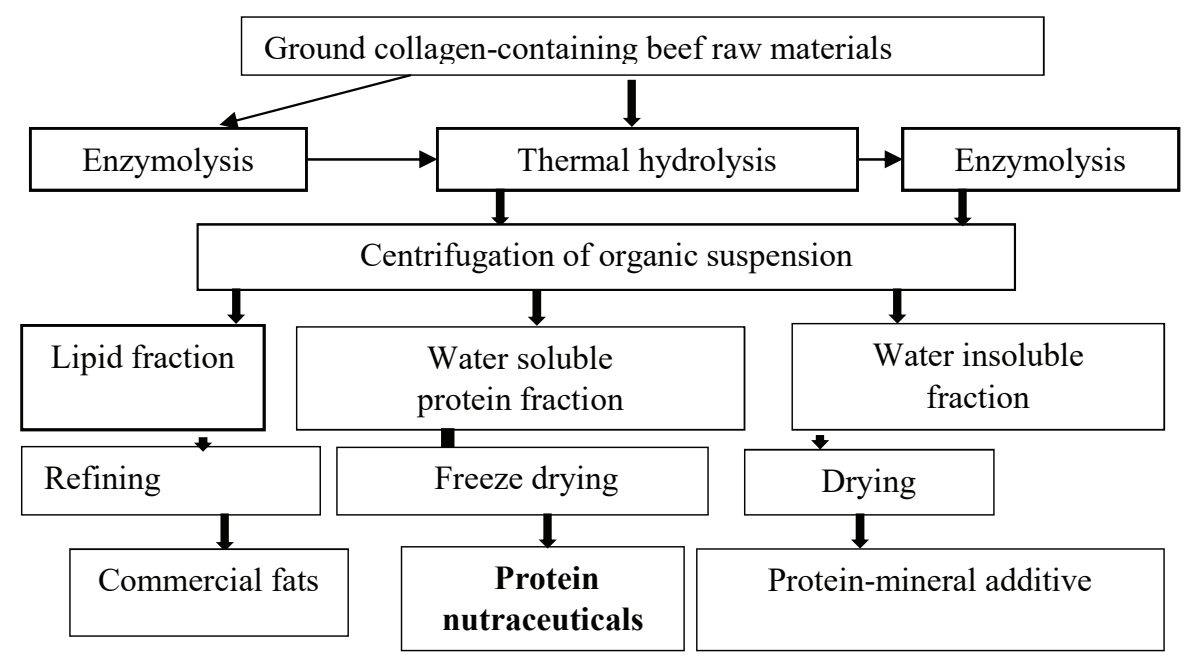

Figure 1. The scheme of collagen-containing raw material processing

weight proteins from beef bones into the dissolved state $[12,13,14,17,19,20,21,22]$. The results of the experiments carried out using various enzyme preparations with varied doses are presented in Table 1.

The obtained data (Table 1) indicate that enzymolysis performed after thermolysis allows a 2-2.5-fold increase in the hydrolysis depth as demonstrated by the growth in FTN. With that, the following regimes can be considered rational: EP doses of $0.75 \%$ and $1 \%$ for Alcalase 2.5 and Protosubtilin G3x with process duration of 4 hours.

The experimental data obtained earlier [13] were used for objective optimization of enzymatic processing of meat and bone raw materials. The data were processed by methods of mathematical statistics to establish significant dependencies between the quantity of generated products of protein enzymatic degradation, doses of enzyme preparations, temperature and enzymolysis duration.

As an optimization parameter, FTN was used, which value demonstrates the concentration of amino acids, ditri- and other oligopetides with the free amino group in a hydrolysate. Creation of enzymolysis models allows regulating the process depth depending on a raw material type, enzyme preparation and process duration.
To this end, initially, the experimental values of FTN obtained in the beef samples at different EP doses and duration were analyzed (Figure 2, [13]). It is seen from the data that this dependence can be described by exponential function (1):

$$
\begin{aligned}
F T N(t, E P) & =F T P_{0}+\left(F T N_{\infty}(E P)-F T N_{0}\right) \times \\
& \times(1-\exp (-\psi(E P) \cdot t),
\end{aligned}
$$

where $F T N_{\infty}(E P)$ and $\psi(E P)$ are empirical functions that are to be determined using the experimental data.

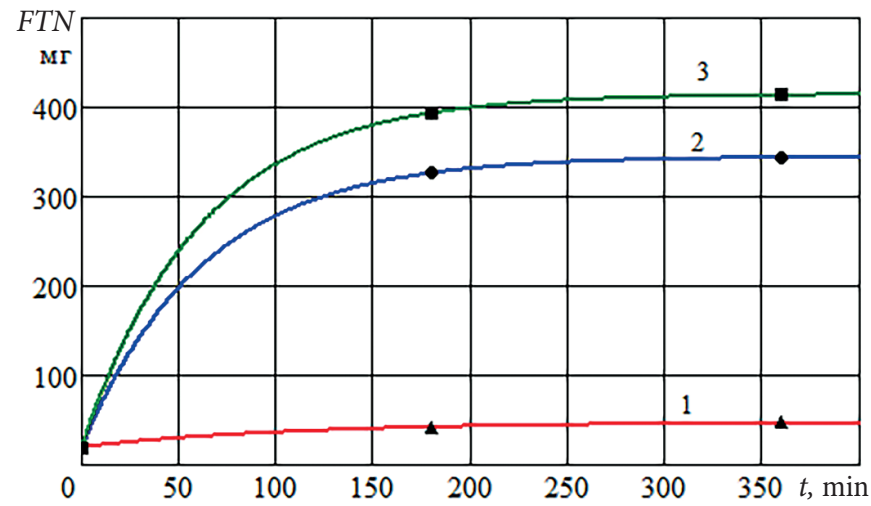

Figure 2. Changes in FTN depending on duration of beef rib enzymolysis at different doses of EP Alcalase 2,5 L: 1-0\%, 2-1\%, 3-2\% (points are experimental data, lines are points of calculation by equation (1)

Table 1. Results of the assessment of the hydrolysis depth of beef rib proteins using various enzymatic preparations (EP)

\begin{tabular}{|c|c|c|c|c|c|c|c|}
\hline $\begin{array}{c}\text { Hydrolysate } \\
\text { samples at } 130^{\circ} \mathrm{C}\end{array}$ & $\begin{array}{l}\text { Dose of EP, \% of } \\
\text { hysrolysate mass }\end{array}$ & $\begin{array}{c}\text { Enzymolysis } \\
\text { duration, hours }\end{array}$ & $\begin{array}{l}\text { FTN, } \\
\mathrm{mg} / 100 \mathrm{~g}\end{array}$ & Samples & $\begin{array}{l}\text { Dose of EP, \% of } \\
\text { hysrolysate mass }\end{array}$ & $\begin{array}{c}\text { Enzymolysis } \\
\text { duration, hours }\end{array}$ & $\begin{array}{c}\text { FTN, } \\
\mathrm{mg} / 100 \mathrm{~g}\end{array}$ \\
\hline $\begin{array}{c}\text { Control } \\
\text { (without EP) }\end{array}$ & 0 & 0 & 212.8 & $\begin{array}{c}\text { Control } \\
\text { (without EP) }\end{array}$ & 0 & 0 & 193.2 \\
\hline \multirow{12}{*}{$\begin{array}{c}\text { With EP Alcalase } \\
2.5 \mathrm{~L}\end{array}$} & \multirow{4}{*}{0.25} & 0 & 238.7 & \multirow{12}{*}{$\begin{array}{c}\text { with EP } \\
\text { Protosubtilin } \\
\text { G3x }\end{array}$} & \multirow{4}{*}{0.5} & 0 & 224.0 \\
\hline & & 2 & 322.0 & & & 2 & 299.6 \\
\hline & & 4 & 351.4 & & & 4 & 305.2 \\
\hline & & 6 & 371.0 & & & 6 & 316.4 \\
\hline & \multirow{4}{*}{0.5} & 0 & 357.4 & & \multirow{4}{*}{0.75} & 0 & 243.6 \\
\hline & & 2 & 337.4 & & & 2 & 347.2 \\
\hline & & 4 & 403.6 & & & 4 & 408.8 \\
\hline & & 6 & 410.2 & & & 6 & 411.6 \\
\hline & \multirow{4}{*}{0.75} & 0 & 290.3 & & \multirow{4}{*}{1.0} & 0 & 268.8 \\
\hline & & 2 & 351.4 & & & 2 & 414.4 \\
\hline & & 4 & 406.0 & & & 4 & 495.6 \\
\hline & & 6 & 417.2 & & & 6 & 498.4 \\
\hline
\end{tabular}
in hydrolysates obtained by thermal hydrolysis at $130^{\circ} \mathrm{C}$ over 1 hour 
The value of the coefficient $\psi$ was found from equation (1):

$$
\psi_{i}=-\frac{1}{180} \cdot \ln \left(1-\left(\frac{F T N_{i 180}-F T N_{0}}{F T N_{i 360}+F T N_{0}}\right)\right.
$$

The values of coefficient $\psi$ found by the equation (2) were also changed according to the exponential dependence and can be presented by empirical functions (3) and (4), which can illustrate the enzymolysis process using EP Alcalase 2,5 $\mathrm{L}$ by means of equation (1):

$$
\begin{aligned}
& F_{\infty}(E P)=47.4+367 \cdot(1-\exp (-1.657 \cdot E P)), \\
& \psi(E P)=0.0910+0.0720 \cdot(1-\exp (-3.214 \cdot E P)) .
\end{aligned}
$$

The use of the regression model (1) in respect to the experimental data on enzymolysis with EP Protosubtilin G3x is reflected in Figure 3.

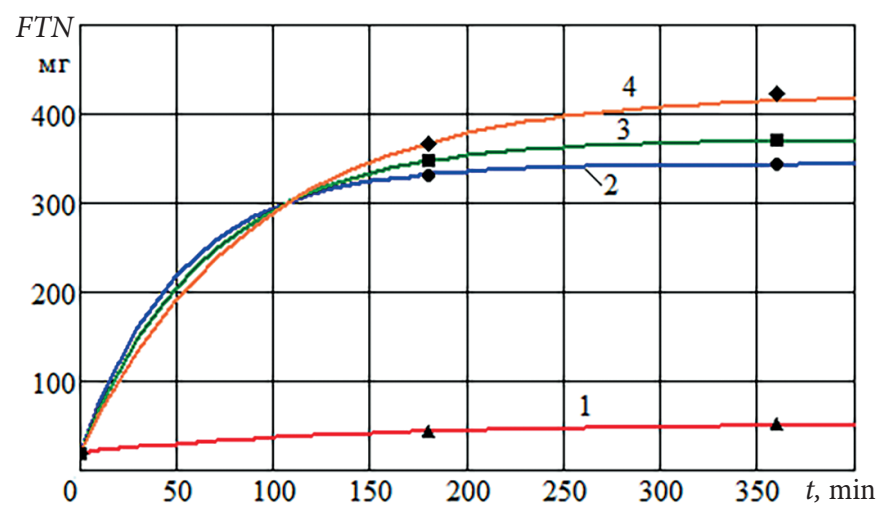

Figure 3. Dependence of FTN in beef rib enzymolysis on process duration at different doses of EP Protosubtilin G3x: 1-0\%, 2-1\%, 3-2\%, $4-3 \%$. Points are experimental data, lines are points of calculation by (1), (3), (4)

Obtained dependencies that link the quantity of enzymolysis products of collagen-containing beef raw materials with regulated process factors allow optimizing its duration with the use of the given EP, above which it is inexpedient to carry out the process as the indicators of protein destruction depth (FTN) change insignificantly. It was established with their use that all enzyme preparations were close in terms of effectiveness for beef rib enzymolysis. To increase quality of protein degradation, it is recommended to use EP compositions (endo- and exopeptidases) combining EP Alcalase 2,5 L, Protamex and Protosubtilin G3x. With that, rational duration is $240-250 \mathrm{~min}$., total dose of enzyme preparations should be close to $3 \%$ of raw material weight.

As a result of experiments on the established recommended values of enzymolysis of preliminarily defatted meat and bone raw materials, the samples of freeze-dried protein hydrolysates were obtained, which overall chemical composition is presented in Table 2.

Analysis of the obtained data (Table 2) shows that in the combined method of hydrolysis (enzymolysis + thermolysis) from beef meat and bone raw materials, it is possible to obtain protein compositions in a dry form with the protein content from $69.45 \%$ to $89.57 \%$, fat from $0.78 \%$ to $9.2 \%$ and minerals from $3.62 \%$ to $15.8 \%$. The highest protein content (about 90\%) was in the samples obtained in combined hydrolysis of beef ribs with preliminary processing with EP Alcalase 1\% over 1 hour with the following enzymolysis with EP Protosubtilin 1\% over 2 hours and thermal treatment at $140{ }^{\circ} \mathrm{C}$.

The obtained data allow proposing a processing technology for highly mineralized collagen containing meat raw materials based on regulated hydrolysis, which enables production of water soluble powders containing over $70 \%$ of highly assimilable proteins - protein nutraceuticals potentially suitable for food purposes. The principle technological scheme of processing collagencontaining meat raw materials and balances of the main chemical substances at the main operations upon production of protein food additives (the main product), fatty and mineral-protein compositions (additional products) are presented in Figure 4.

The technological scheme (Figure 4) presents the chemical composition and calculated values of a recovery degree for the main raw material components (dry matter, protein, fat and minerals) at the key operations of the hydrolytic technology (moist semi-finished products, dry finished products). The technological scheme illustrates the chemical transformation of raw materials into food additives by the example of the enzymatic-thermal hydrolysis of the beef bone mixture (tibia, fibula and costal bones). It is seen that when processing using these scheme, $85.2 \mathrm{~kg}$ of the freeze-dried protein powder can be obtained from $1000 \mathrm{~kg}$ of raw materials without waste. This protein powder contains $83.3 \%$ of protein (yield of proteins from raw

\begin{tabular}{|c|c|c|c|c|c|}
\hline \multirow{2}{*}{ No. Characteristics of raw materials and hydrolysis conditions } & \multicolumn{5}{|c|}{ Protein hydrolysate, indicators, $\%$ wt } \\
\hline & Water & Dry substances & Fat & Minerals & Protein \\
\hline $\begin{array}{l}\text { 1. Beef tibia and fibula: enzymolysis, EP Alcalase } 1 \% \text { ( } 2 \text { hours })+ \\
\text { EP Protosubtilin } 1 \% \text { ( } 2 \text { hours) }\end{array}$ & 7.55 & 92.45 & 3.24 & 13.48 & 75.73 \\
\hline $\begin{array}{l}\text { 2. Beef tibia and fibula: enzymolysis, EP Alcalase } 0.5 \% \text { ( } 2 \text { hours })+ \\
\left.\text { EP Protosubtilin } 0.5 \% \text { ( } 2 \text { hours })+ \text { thermolysis } 140^{\circ} \mathrm{C} \text { ( } 1 \text { hour }\right)\end{array}$ & 5.48 & 94.52 & 9.24 & 15.83 & 69.45 \\
\hline $\begin{array}{l}\text { 3.Beef rib: enzymolysis, EP Alcalase } 0.5 \% \text { ( } 2 \text { hours })+ \\
\text { EP Protosubtilin } 0.5 \% \text { ( } 2 \text { hours) + thermolysis } 140{ }^{\circ} \mathrm{C}(1 \text { hour })\end{array}$ & 5.43 & 94.57 & 4.02 & 4.41 & 86.14 \\
\hline $\begin{array}{l}\text { 4. Beef rib: enzymolysis EP Alcalase } 1 \%(2 \text { hours })+ \\
\left.\text { EP Protosubtilin } 1 \% \text { ( } 2 \text { hours })+ \text { thermolysis } 140^{\circ} \mathrm{C} \text { ( } 1 \text { hour }\right)\end{array}$ & 6.03 & 93.97 & 0.78 & 3.62 & 89.57 \\
\hline
\end{tabular}

Table 2. Chemical composition of freeze-dried protein hydrolysates obtained using different EP by various regimes of hydrolysis of collagen-containing beef raw materials 


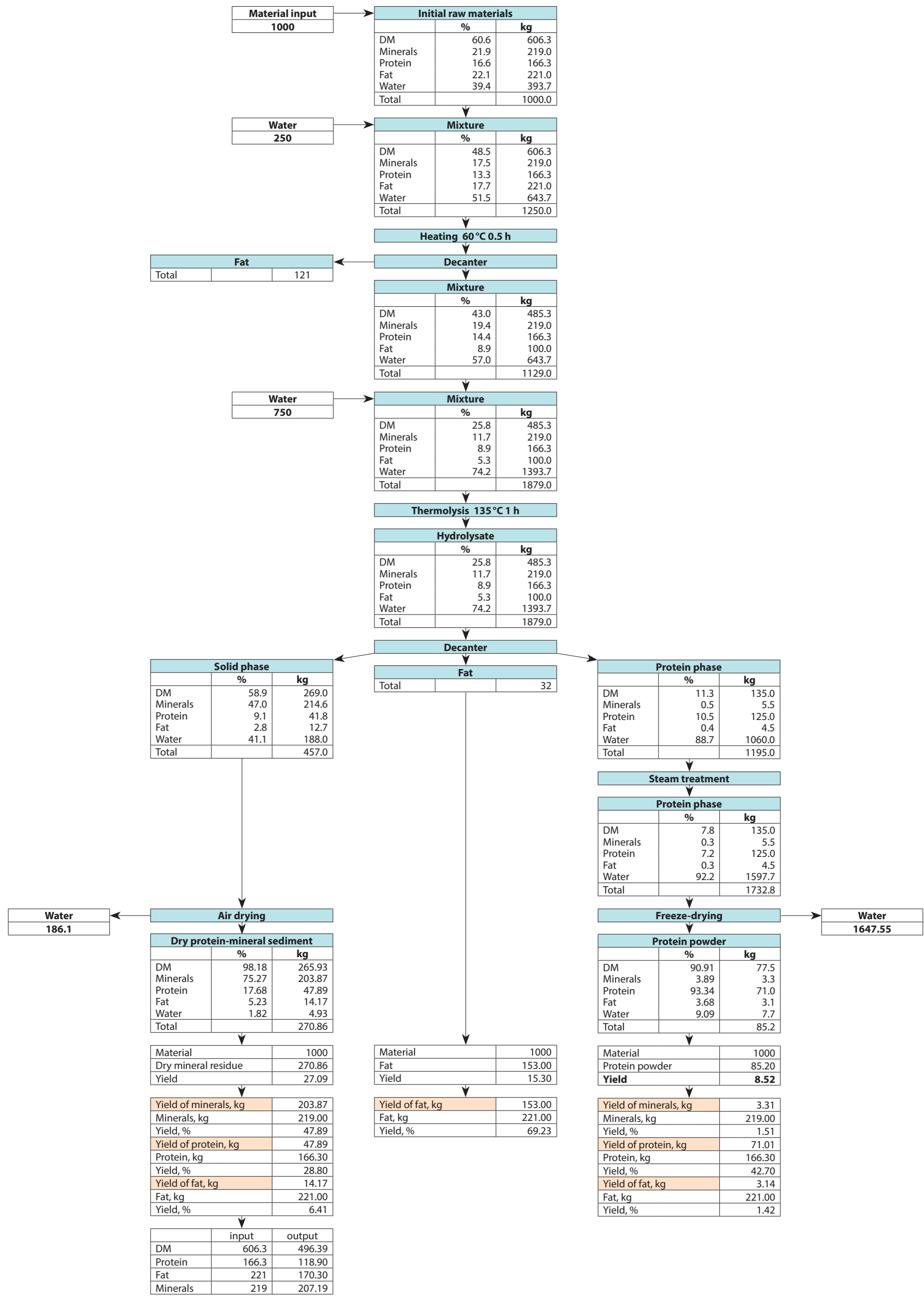

Figure 4. Technological scheme and mass post-operational balances of the main chemical substances in enzymatic thermal hydrolysis of the beef bone mixture (tibia, fibula and costal bones) 
materials $71 \%$ ), $221 \mathrm{~kg}$ of fat (yield of fat from raw materials $69.2 \%$ ) and $270 \mathrm{~kg}$ of the dry mineral-protein additive containing $75.3 \%$ of minerals, $17.7 \%$ of proteins, $5.2 \%$ of fat. Therefore, the rationality and high workability of processing highly mineralized collagen-containing beef raw materials according to the proposed hydrolytic technology was demonstrated.

To assess the nutritional value of the protein fraction of the obtained water soluble beef hydrolysates, its quality was assessed by determining the amino acid composition, molecular weight and fractional composition of peptides, as well as their functional-technological properties by standard indicators.

The results of the amino acid composition of the protein formulations obtained by different hydrolytic methods and illustrating their anabolic potential are presented in Table 3.

As shown in Table 3, the amino acid composition in all samples was close irrespective of their production method, and corresponds to collagen meat raw materials by its amino acid composition $[1,2,4,7,9,10,14,16]$. Glycine accounts for the main quantity of amino acids in the hydrolysates (23.1-23.5 g/100 g protein), which indicates a possibility to use them in the composition of biologically active products of the neuroprotective direction as glycine is a functional neurotransmitter and is recommended for the use in the composition of neuroprotective BAAs $[1,10,24]$. The obtained hydrolysates are of conditionally full-value by the amino acid composition as they contain all essential amino acids (without regard for tryptophan); although, in significantly lower amounts compared to ideal protein. The crucial essential amino acid in hydrolysates is lysine (3.55-4.20 g/100 g protein), which has many important functions in the body (anabolic material for muscles, immunomodulator, facilitates calcium assimilation, has a sedative effect). The lysine content in these hydrolysates is also important because its content in plant proteins (from cereals, legumes) is, as a rule, lowered. This means that it is rational to use the obtained hydrolysates in the composition of combined products with plant components. In regard to the absolute content, high amounts of non-essential amino acids are present in the hydrolysates of beef meat and bone raw materials. After glycine, proline stands out among quantitatively prevalent amino acids (11.6-13.1 $\mathrm{g} / 100 \mathrm{~g}$ protein) being a peculiar kind of the collagen tissue indicator. Also, increased amounts of alanine (9.6-10.2 g/ $100 \mathrm{~g}$ protein), glutamic and aspartic acids, arginine (10.6$11.6 \mathrm{~g} / 100 \mathrm{~g}$ protein and $5.8-6.3 \mathrm{~g} / 100 \mathrm{~g}$ protein; 7.6-7.9 g/ $100 \mathrm{~g}$ protein) were established in the hydrolysates. These amino acids also have important physiological effects in the body $[1,24,26]$; with that, it is important that they are in the assimilable form.

The indicators of the amino acid balance of protein hydrolysates obtained by different methods that were calculated by conventional equations [9] are presented in Table 4.

Table 3. Comparative amino acid composition of protein hydrolysates of beef ribs obtained by different regimes

\begin{tabular}{|c|c|c|c|}
\hline \multirow[b]{2}{*}{ Amino acids (AA) } & \multicolumn{3}{|c|}{$\begin{array}{l}\text { Amino acid content in protein hydrolysates of beef ribs, } \\
\qquad \mathrm{g} / 100 \mathrm{~g} \text { of protein }\end{array}$} \\
\hline & $\begin{array}{l}\text { Thermolysis: } \\
140^{\circ} \mathrm{C}, 1 \text { hour }\end{array}$ & $\begin{array}{c}\text { Enzymolysis: EP Alcalase } 0.5 \% \\
(2 \text { hours) + EP Protosubtilin } 0.5 \% \\
\text { ( } 2 \text { hours })+ \text { thermolysis } 140{ }^{\circ} \mathrm{C}, 1 \text { hour }\end{array}$ & $\begin{array}{c}\text { Enzymolysis: EP Alcalase } 1 \% \\
(2 \text { hours })+\text { thermolysis } 135^{\circ} \mathrm{C}, \\
1 \text { hour }\end{array}$ \\
\hline Aspartic acid (Asp) + asparagine (Asn) & $6.1 \pm 0.80$ & $6.3 \pm 0.8$ & $5.8 \pm 0.8$ \\
\hline Glutamic acid (Glu) + glutamine (Gln) & $10.9 \pm 1.20$ & $11.6 \pm 1.3$ & $10.6 \pm 1.2$ \\
\hline Histidine (His) & $1.09 \pm 0.30$ & $1.18 \pm 0.32$ & $1.20 \pm 0.33$ \\
\hline Serine (Ser) & $3.16 \pm 0.28$ & $3.39 \pm 0.31$ & $3.11 \pm 0.28$ \\
\hline Arginine (Arg) & $7.9 \pm 0.80$ & $7.7 \pm 0.70$ & $7.6 \pm 0.70$ \\
\hline Glycine (Gly) & $23.1 \pm 2.30$ & $23.1 \pm 2.30$ & $21.5 \pm 2.20$ \\
\hline Threonine (Thr) & $1.88 \pm 0.15$ & $2.19 \pm 0.18$ & $2.05 \pm 0.17$ \\
\hline Alanine (Ala) & $9.6 \pm 1.00$ & $10.2 \pm 1.10$ & $9.9 \pm 1.10$ \\
\hline Tyrosine (Tyr) & $0.8 \pm 0.23$ & $1.01 \pm 0.29$ & $0.97 \pm 0.28$ \\
\hline Valine (Val) & $2.66 \pm 0.35$ & $3.30 \pm 0.40$ & $3.05 \pm 0.40$ \\
\hline Methionine (Met) & $0.70 \pm 0.08$ & $0.75 \pm 0.09$ & $0.84 \pm 0.10$ \\
\hline Proline (Pro) & $13.1 \pm 2.00$ & $11.6 \pm 1.70$ & $12.2 \pm 1.80$ \\
\hline Isoleucine (Ile) & $1.59 \pm 0.13$ & $1.79 \pm 0.14$ & $1.70 \pm 0.13$ \\
\hline Phenylalanine (Phe) & $2.16 \pm 0.29$ & $2.52 \pm 0.34$ & $2.45 \pm 0.33$ \\
\hline Leucine (Leu) & $3.44 \pm 0.32$ & $4.27 \pm 0.39$ & $4.12 \pm 0.38$ \\
\hline Lysine (Lys) & $3.55 \pm 0.34$ & $4.20 \pm 0.40$ & $3.95 \pm 0.38$ \\
\hline Cystine (Cys) & $<0.035$ & $0.091 \pm 0.019$ & $0.082 \pm 0.017$ \\
\hline Tryptophan (Trp) & & was destroyed upon sample preparati & \\
\hline
\end{tabular}


Table 4. Comparative assessment of biological value indicators in protein hydrolysates from beef ribs obtained by different methods

\begin{tabular}{|c|c|c|c|c|c|c|c|}
\hline \multirow{3}{*}{$\begin{array}{c}\text { Essential } \\
\text { amino acids (AA) }\end{array}$} & \multirow{3}{*}{$\begin{array}{l}\text { AA content } \\
\text { in protein FAO } \\
\mathrm{WHO}, \mathrm{g} / 100 \mathrm{~g}\end{array}$} & \multicolumn{6}{|c|}{ Hydrolysates from beef ribs obtained by different methods } \\
\hline & & \multicolumn{2}{|c|}{$\begin{array}{l}\text { Thermolysis: } \\
140^{\circ} \mathrm{C}, 1 \text { hour } \\
(4 / 73)\end{array}$} & \multicolumn{2}{|c|}{$\begin{array}{c}\text { Enzymolysis: EP Alcalase } 0.5 \% \\
(2 \text { hours })+\text { EP Protosubtilin } \\
0.5 \%(2 \text { hours })+\text { thermolysis } \\
140{ }^{\circ} \mathrm{C}, 1 \text { hour }\end{array}$} & \multicolumn{2}{|c|}{$\begin{array}{c}\text { Enzymolysis: EP Alcalase } 1 \% \\
(2 \text { hours })+\text { thermolysis } 135^{\circ} \mathrm{C}, \\
1 \text { hour }\end{array}$} \\
\hline & & $\begin{array}{l}\text { AA content, } \\
\text { g / } 100 \text { g protein }\end{array}$ & AA score, $\%$ & $\begin{array}{l}\text { AA content, } \\
\text { g / } 100 \text { g protein }\end{array}$ & AA score, $\%$ & $\begin{array}{l}\text { AA content, } \\
\text { g / } 100 \text { g protein }\end{array}$ & AA score, $\%$ \\
\hline Ile + Leu & 9.10 & 4.99 & 54.83 & 6.06 & 66.59 & 5.82 & 63.96 \\
\hline Lys & 4.80 & 3.55 & 73.96 & 4.20 & 87.5 & 3.95 & 82.29 \\
\hline Val & 4.00 & 2.66 & 66.50 & 3.30 & 82.5 & 3.05 & 76.25 \\
\hline Met + Cys & 2.30 & 0.73 & 31.96 & 0.84 & 36.52 & 0.92 & 40.00 \\
\hline Thr & 2.50 & 1.88 & 75.20 & 2.19 & 87.6 & 2.05 & 82.00 \\
\hline Phe + Tyr & 4.10 & 2.96 & 72.19 & 3.53 & 86.10 & 3.42 & 83.41 \\
\hline $\operatorname{Trp}$ & 0.60 & - & - & - & - & - & - \\
\hline Total: & 27.40 & 16.77 & & 20.12 & & 19.21 & \\
\hline \multicolumn{2}{|c|}{$\begin{array}{l}\text { Coefficient of amino-acid score } \\
\text { difference (CAASD), \% }\end{array}$} & \multicolumn{2}{|c|}{26.12} & \multicolumn{2}{|c|}{32.52} & \multicolumn{2}{|c|}{26.84} \\
\hline \multicolumn{2}{|c|}{ Biological value (BV), \% } & \multicolumn{2}{|c|}{73.88} & \multicolumn{2}{|c|}{67.47} & \multicolumn{2}{|c|}{73.16} \\
\hline \multicolumn{2}{|c|}{ Coefficient of utility, $U$, unit fractions } & \multicolumn{2}{|c|}{0.51} & \multicolumn{2}{|c|}{0.49} & \multicolumn{2}{|c|}{0.56} \\
\hline
\end{tabular}

It is seen from Table 4 that despite a low content of essential amino acids in the hydrolysates, they are quite balanced relative to ideal protein, which is indicated by the values of the biological value (BV) in a range of $67.47 \%$ to $73.88 \%$. With that, the best calculated amino acid balance was noticed in hydrolysates obtained with thermolysis (73.88\%). On the other hand, the best value in terms of the utility (U) indicator was in the hydrolysates obtained by the combined method using EP Alcalase with preliminary enzymolysis with the following thermal hydrolysis.

The obtained data demonstrate the prospects of using obtained protein hydrolysates of meat and bone raw materials as food additives both in the composition of multicomponent food products and as biologically active additives. In the latter case, the nutritional effect will be conditioned by the presence of the amino acids glycine, proline, alanine, aspartic acid and glutamic acid having the physiological action, including the osteotropic effect $[1,25]$.

The physiological functionality of the obtained protein hydrolysates was assessed by detection of the molecular weight and fractional composition of the contained low molecular weight peptides with the molecular weight of less than $100 \mathrm{kDa}$ [10]. In these investigations, a special attention was paid at the quantitative and qualitative identification of the low molecular weight peptide fractions with the molecular weight less than $10 \mathrm{kDa}$ that are assigned to active functional peptides with proved functional effects $[11,12]$.

The solubility index of protein hydrolysates indicating their transition into the dissociated state and, thus, assimilability in the body was studied in the preparation operations. The summarized results of the fractional molecular composition of the freeze-dried hydrolysates by peptide groups with a molecular weight of up to $100 \mathrm{kDa}$ are presented in Table 5, Figure 5 and Figure 6.

Table 5. Characteristics of solubility of freeze-dried protein hydrolysates and their differentiation by the fractional molecular composition of low molecular weight peptides

\begin{tabular}{|c|c|c|c|c|c|}
\hline 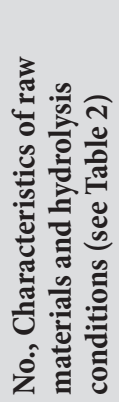 & 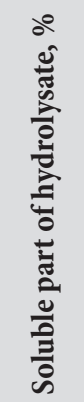 & 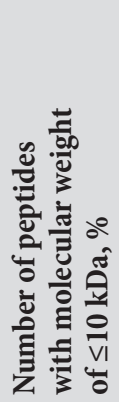 & 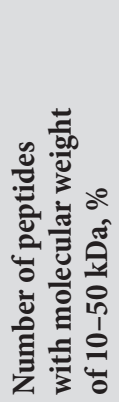 & 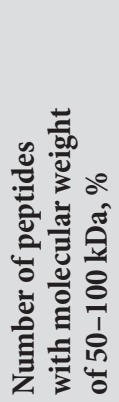 & 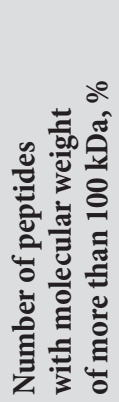 \\
\hline 1 & 90.4 & 94.18 & 4.99 & 0.83 & 0 \\
\hline 2 & 95.4 & 93.78 & 5.27 & 0.95 & 0 \\
\hline 3 & 99.7 & 47.38 & 36.95 & 9.19 & 6.48 \\
\hline 4 & 100.0 & 43.61 & 38.02 & 10.60 & 7.77 \\
\hline
\end{tabular}

It can be seen from Table 5 that solubility of the obtained protein products is high (more than 90\%) and is determined by a degree of raw material grinding. In case of using tubular bones, when fine grinding was difficult, solubility of obtained protein hydrolysates was lower (90.4-95.4\%). When grinding less strong costal bones, protein hydrolysates with increased solubility (99.7-100\%) were obtained. It is necessary to note that the quantity of low molecular weight peptides with a molecular weight of less than $10 \mathrm{kDa}$ in the soluble part of the hydrolysates was significantly higher than in the similar samples from costal bones (93.78-94.18\%). 

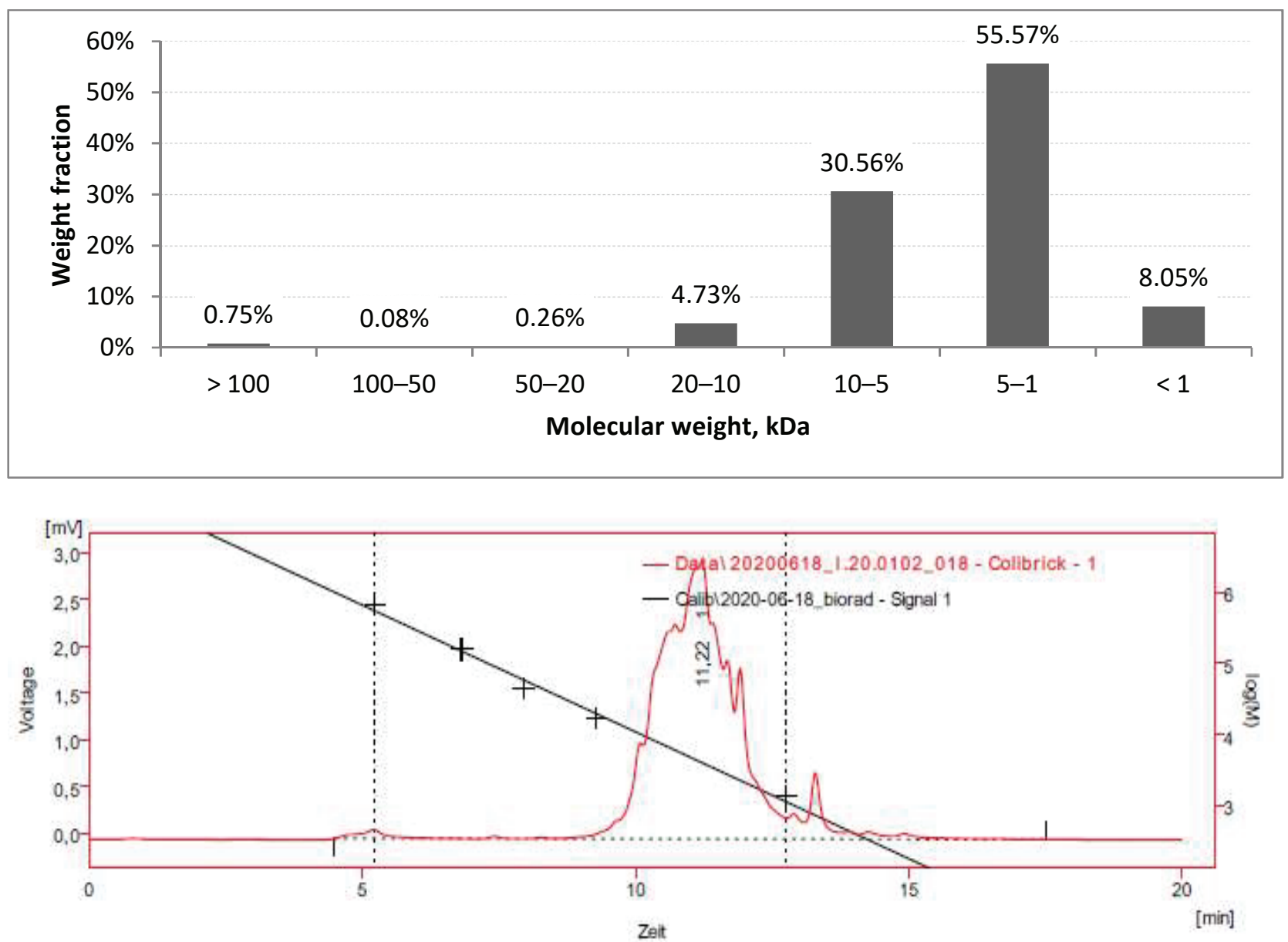

Figure 5. Fractional distribution of peptides by molecular weight in the freeze-dried protein hydrolysate produced by enzymolysis of beef ribs (Alcalase 1\% (2 hours) + Protosubtilin 1\% (2 hours)
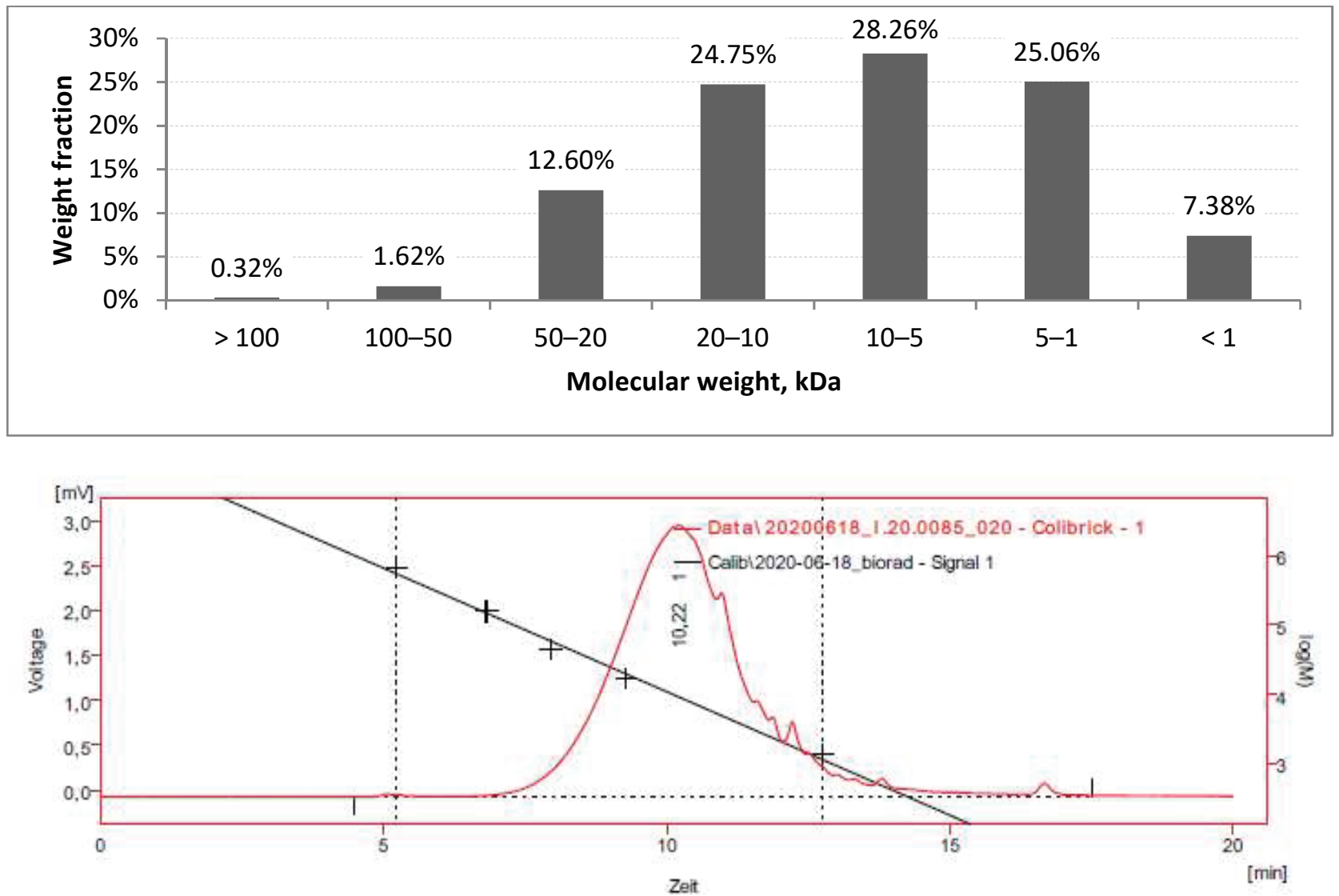

Figure 6. Fractional distribution of peptides by molecular weight in the freeze-dried protein hydrolysate produced by thermolysis $\left(160^{\circ} \mathrm{C}, 1\right.$ hour $)$ 
Table 6. Results of assessing the emulsifying capacity (EC) of freeze-dried protein hydrolysates produced from different collagencontaining beef raw materials at different processing regimes

\begin{tabular}{|c|c|c|c|c|}
\hline Raw materials & Regime of hydrolysis & $\begin{array}{l}\text { Volume of } \\
\text { emulsion, } \mathrm{ml}\end{array}$ & EC, $\%$ & Stability of emulsion, \% \\
\hline Beef tibia and fibula & Thermolysis: $140^{\circ} \mathrm{C}, 1$ hour & 110 & 220 & 100 \\
\hline Beef tibia and fibula & Thermolysis: $150^{\circ} \mathrm{C}, 1$ hour & 100 & 200 & 100 \\
\hline Beef tibia and fibula & Thermolysis: $160^{\circ} \mathrm{C}, 1$ hour & 110 & 220 & 100 \\
\hline Beef tibia and fibula & $\begin{array}{c}\text { enzymolysis, EP Alcalase } 1 \%(2 \text { hours })+\text { EP } \\
\text { Protosubtilin } 1 \%(2 \text { hours })+\text { thermolysis: } \\
140^{\circ} \mathrm{C}, 1 \text { hour }\end{array}$ & 115 & 230 & $\begin{array}{l}\text { Emulsion was separated upon } \\
\text { centrifugation and settling }\end{array}$ \\
\hline Beef ribs & $\begin{array}{c}\text { Enzymolysis, EP Alcalase } 0.5 \% \text { ( } 2 \text { hours })+ \text { EP } \\
\text { Protosubtilin } 0.5 \% \text { ( } 2 \text { hours })+ \text { thermolysis } 140^{\circ} \mathrm{C} \\
\text { (1 hour) }\end{array}$ & 106 & 212 & $\begin{array}{l}\text { Emulsion was stable upon } \\
\text { settling, but was separated } \\
\text { upon centrifugation }\end{array}$ \\
\hline Beef ribs & $\begin{array}{l}\text { Enzymolysis, EP Alcalase } 0.1 \%(2 \text { hours })+ \\
\text { thermolysis } 130^{\circ} \mathrm{C}(1 \text { hour })+\text { enzymolysis EP } \\
\text { Alcalase } 1 \%(2 \text { hours })+\text { thermolysis } 130^{\circ} \mathrm{C}(1 \text { hour })\end{array}$ & 115 & 230 & $\begin{array}{l}\text { Emulsion was separated upon } \\
\text { centrifugation and settling }\end{array}$ \\
\hline Beef ribs & $\begin{array}{c}\text { Enzymolysis, EP pancreatin: } 0.5 \% ; 0.75 \% ; 1 \% \\
\text { ( } 2 \text { hours })\end{array}$ & $\begin{array}{l}95 \\
\text { in all three } \\
\text { samples }\end{array}$ & $\begin{array}{l}190 \\
\text { in all three } \\
\text { samples }\end{array}$ & $\begin{array}{l}\text { Emulsion was separated upon } \\
\text { centrifugation and settling in } \\
\text { all three samples }\end{array}$ \\
\hline
\end{tabular}

Analysis of the obtained data on molecular fractional distribution of peptides in the water soluble parts of freezedried hydrolysates of meat and bone beef raw materials (Table 5, Figure 5 and Figure 6) allows making a conclusion that these protein products can be considered concentrates of low molecular weight active peptides. It is known that these peptides are highly functional in the body, and by a degree of assimilability, they can be assigned to protein nutraceuticals that exert positive physiological effects. It is important that the number of peptides with the molecular weight of less than $100 \mathrm{kDa}$ was close to $100 \%$ in all samples. With that, the content of the especially important low molecular weight fraction with the molecular weight of less than $10 \mathrm{kDa}$ (active peptides) was 43.61 to $94.18 \%$ depending on a hydrolysis method. Maximum quantity of active peptides was in protein products obtained by the enzymolysis method without thermal treatment (Figure 5). This hydrolysate is basically a mixture of pure amino acids, di- and tripetides that have the immunomodulating, antioxidant, anabolic and other physiological effects [1,2,24,27]. These peptide nutraceuticals can be recommended for using in the composition of food BAAs that increase the immune status of the body.

To substantiate recommendations on the use of freezedried protein nutraceuticals in the food systems, their functional technological properties were assessed by indicators that demonstrate their structure-forming abilities in the multicomponent systems. The emulsifying capacity (EC), water holding capacity (WHC), water binding capacity (WBC) and fat binding capacity (FBC) were measured in the test samples. The obtained results are presented in Table 6 and Table 7.

Results of the analysis of the data in Table 6 and Table 7 show that freeze-dried protein hydrolysates produced by thermolysis of tubular bones during one hour at temperatures of $140-160{ }^{\circ} \mathrm{C}$, have the high emulsifying capacity $(200-220 \%$ of the mass of the used oil). With that, the de- veloped emulsion was very stable, was not separated upon centrifugation at $2700 \mathrm{rpm}$, and retained its stability (was not separated into layers) up to 4 days of holding at a temperature of about $20^{\circ} \mathrm{C}$.

Protein hydrolysates produced by the combined method (enzymolysis with different enzyme preparations + thermal hydrolysis) as well as enzymolysis with pancreatin did not have the high emulsion stability upon the high emulsifying capacity (190-230\%). Emulsions obtained with their use were separated into the oil and water fractions in all cases upon centrifugation at $2700 \mathrm{rpm}$ and settling.

It is obvious that enzymatic treatment by a complex of enzymes alcalase and protosubtilin in different combinations allows obtaining protein hydrolysates from both types of raw materials. These protein hydrolysates have the high quantity of low molecular weight peptides and free amino acids, and possess the emulsifying capacity due to an increased number of opened functional groups. With that, however, their decreased molecular weight does not allow formation of a stable structure in the emulsion and it is quickly separated into the fatty and aqueous fractions.

Table 7. Water holding capacity (WHC), water binding capacity (WBC) and fat holding capacity (FHC) of freeze-dried protein hydrolysates from beef tibia and fibula obtained at different regimes of thermolysis

\begin{tabular}{|c|c|c|c|c|}
\hline Raw materials & $\begin{array}{c}\text { Regime } \\
\text { of hydrolysis }\end{array}$ & $\begin{array}{l}0 \\
0 \\
0 \\
3 \\
3\end{array}$ & 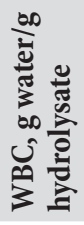 & 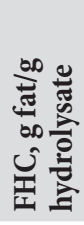 \\
\hline $\begin{array}{l}\text { Beef tubular bones } \\
\text { (tibia and fibula) }\end{array}$ & $\begin{array}{c}\text { Thermolysis } 1 \text { hour, } \\
140^{\circ} \mathrm{C}\end{array}$ & 66.6 & 0.89 & 82.3 \\
\hline $\begin{array}{l}\text { Beef tubular bones } \\
\text { (tibia and fibula) }\end{array}$ & $\begin{array}{c}\text { Thermolysis } 1 \text { hour, } \\
150^{\circ} \mathrm{C}\end{array}$ & 43.3 & 0.97 & 118 \\
\hline $\begin{array}{l}\text { Beef tubular bones } \\
\text { (tibia and fibula) }\end{array}$ & $\begin{array}{c}\text { Thermolysis } 1 \text { hour, } \\
160^{\circ} \mathrm{C}\end{array}$ & 33.3 & 0.98 & 197 \\
\hline
\end{tabular}


Analysis of these hydrolysates regarding functionaltechnological properties (Table 6) shows that high temperature thermolysis enables obtaining protein products with quite high structure-forming capacities. For example, WHC of hydrolysates at a level of $33.3 \%-66.6 \%$ points to a potential possibility to retain $33 \%-66 \%$ of water by these hydrolysates, while WBC of these samples was close to one (0.89-0.98) indicating high strength capacities of bound water retention. However, the hydrolysates showed the highest indicators of technological functionality in fat sorption. It is known that FHC at a level of $100 \mathrm{~g} / \mathrm{g}$ is typical for pure protein preparations [3], while protein products obtained by thermal hydrolysis at $150-160^{\circ} \mathrm{C}$ are superior to them by fat holding capacity (118-197 $\mathrm{g}$ fat/g).

Analysis of functional-technological properties of protein hydrolysates (Table 7) also shows that with an increase in a thermolysis temperature from 140 to $160^{\circ} \mathrm{C}$, a decrease in the water holding capacity (WHC) and an increase in water binding (WBC) and fat holding (FHC) capacities were observed. This dependence can be explained by intensification of protein molecule destruction reflected in the values of molecular weights of obtained peptides. The higher the hydrolysis temperature, the lower the molecular weight of generated peptides and the higher the weight fraction of low molecular weight peptides in the protein mixture (Table 4, Figure 5). With that, the WHC values in hydrolysates dropped from $66.6 \%$ (thermolysis at $140^{\circ} \mathrm{C}$ ) to $33.3 \%$ (thermolysis at $160^{\circ} \mathrm{C}$ ), and WCC and FHC in the same samples grew from 0.89 to $0.98 \mathrm{~g}$ water/g and from 82.3 to $197 \mathrm{~g}$ fat/g hydrolysate. It is necessary to note the positive effect of the thermolysis temperature growth on an increase in the fat holding capacity (FHC) of the hydrolysates, which rose more than twofold in the protein products obtained at 160 ${ }^{\circ} \mathrm{C}$ compared to hydrolysates generated in thermolysis at 140 ${ }^{\circ} \mathrm{C}$. This property can be applied when using freeze-dried hydrolysates in food systems with the increased fat content.

The obtained results indicate prospects and rationality of using dry protein nutraceuticals in different food systems. They correspond to the requirements for food additives in terms of sensory properties, chemical composition and safety. All protein nutraceuticals have a natural color from beige to light-brown, weak meat odor and meat flavor with mild gelatin tint, do not bring off-flavor or unpleasant flavor to other products. When consumed orally, protein compositions with prevalence of peptides with the molecular weight of less than $10 \mathrm{kDa}$ have insignificant bitter off-flavor, which is necessary to take into account in developing corresponding food systems. In this case, it is recommended to introduce them in the encapsulated form as food BAAs or consume them with food ingredients having compensatory favor characteristics.

The normative documentation "Food technological additive. Collagen hydrolysate" was developed for produced protein nutraceuticals. In the special experiments, several recipes were developed using these additives. In particu- lar, consumers gave high scores to specialized restructured meat products (souse, wiener-type sausages) with the osteotropic direction. Protein additives obtained from beef bones by combined hydrolysis were additionally introduced into the recipes of these products in an amount of $2-3 \%$ of food weight. Enriched products had high sensory properties and were recommended to the elderly as gerodietetic nutrition intended for strengthening the locomotor apparatus.

Based on the obtained results, recommendations on the use of the obtained protein nutraceuticas in food production were developed. It is recommended to use protein additives from collagen-containing beef raw materials as a source of functional amino acids with the osteotropic direction in the composition of specialized and personalized enriched food products designed for specific population groups (for example, patients suffering from collagenosis). These products will be beneficial for broad layers of the population for prophylaxis and strengthening of the locomotor apparatus. In the latter case, they can be especially in demand among the elderly, sportspersons, workers with increased physical loads and others. The use of low molecular weight protein nutraceuticals is promising in the composition of several protein multicomponent BAAs as a source of active peptides intended for compensation of deficiency in the amino acids - neurotransmitters (glycine, alanine) and others increasing physiological and immune functions of the body $[1,2,13,17,18,24,27]$.

\section{Conclusion}

As a result of the experimental study, the rational ways of obtaining low molecular weight protein components (peptides, oligopeptides and amino acids) from highly mineralized collagen-containing beef raw materials (beef tibia, fibula and costal bones) by enzymatic, thermal and enzymatic-thermal methods. These protein components are recommended for using as food and biologically active additives - protein nutraceuticals.

The rational technological scheme and optimal regimes of deep hydrolysis of beef raw materials were established for producing low molecular weight protein nutraceuticals. The molecular fractional composition, amino acid composition and indicators of amino acid balance were determined; emulsifying, water holding, water binding and fat binding capacities were established in the protein compositions. The obtained results indicate the high biological value, functionality and processability of protein nutraceuticals from meat and bone beef raw materials.

The recommendations on the use of protein nutraceuticals from beef raw materials in the composition of food BAAs were substantiated for increasing physiological and immune status of the body and as a source of multifunctional amino acids. Protein nutraceuticals are promising enriching agents in specialized and personalized food products with the osteotropic direction. 


\section{REFERENCES}

1. Yao, Y., Yuan, X., Wang, M., Han, L., Liu, X. (2021). Efficient pretreatment of waste protein recovery from bovine bones and its underlying mechanisms. Waste and Biomass Valorization, https://doi.org/10.1007/s12649-021-01372-7 (unpublished data)

2. Chuck-Hernández, C., Ozuna, C. (2019). Proteins: Sustainable Source, Processing and Applications. Chapter in a book: Protein Isolates From Meat Processing By-Products. 131-162 https://doi.org/10.1016/B978-0-12-816695-6.00005-2

3. Glotova, I.A., Litovkin A. N. (2016). Processing of poultry heads and legs with production of food modules Meat industry, 6, 48-50. (In Russian)

4. Akpor, O. B., Odesola, D. E., Thomas, R. E., Oluba, O. M. (2019). Chicken feather hydrolysate as alternative peptone source for microbial cultivation. F1000Research, 7, Article 1918 https://doi. org/10.12688/f1000research.17134.3

5. Akpor, O. B., Deborah, J. E., Oluba, 0. M. (2018). Comparative decolouration of crystal violet dye using chicken feather fibre, chemical oxidation and bacterial cells. Journal of Environmental Science and Technology, 11(5), 246-253. https://doi. org/10.3923/jest.2018.246.253

6. Sinkiewicz, I., Śliwińska, A., Staroszczyk, H., Kołodziejska, I. (2017). Alternative methods of preparation of soluble keratin from chicken feathers. Waste and Biomass Valorization, 8(4), 1043-1048. . https://doi.org/10.1007/s12649-016-9678-y

7. Tesfaye, T., Sithole, B., Ramjugernath, D. (2018). Valorisation of chicken feather barbs: Utilisation in yarn production and technical textile applications. Sustainable Chemistry and Pharmacy, 8, 38-49. https://doi.org/10.1016/j.scp.2018.02.002

8. Mezenova, O. Ya., Volkov, V.V., Moersel, T., Hoehling, A., Grimm, T., Mezenova, N. Yu. (2018). Comparative assessment of hydrolysis methods for production of protein products from collagen-containing fish raw material and evaluation of their quality. KSTU NEWS, 49, 126-144. (In Russian)

9. Mezenova, O. Ya., Volkov, V.V., Moersel, T., Grimm, T., Kuehn, S., Hoehling, A., Mezenova, N. Yu. (2018). A comparative assessment of hydrolysis methods used to obtain fish collagen peptides and investigation of their amino acid balance. Proceedings of universities. Applied chemistry and biotechnology, 8, 4(27), 8394. https://doi.org/10.21285/2227-2925-2018-8-4-83-94 (In Russian)

10. Toldrá, F., Mora, L., Reig, M. (2016). New insights into meat by-product utilization. Meat Science, 120, 54-59. https://doi. org/10.1016/j.meatsci.2016.04.021

11. Saeed, M., Khan, M. I., Arshad, R., Farooq, M. A., Rehman, M. A., Ishaque, A. (2020). Exploring the anti-cancerous and antiinflammatory potential of bovine meat by-product hydrolysates. Journal of Biological Regulators and Homeostatic Agents, 34(5), 1875-1878.

12. Cheng, D., Liu, Y., Ngo, H. H., Guo, W., Chang, S. W., Nguyen, D. D. at al. (2021). Sustainable enzymatic technologies in waste animal fat and protein management. Journal of Environmental Management, 284, Article 112040. https://doi.org/10.1016/j. jenvman.2021.112040

13. Mezenova, N. Yu., Agafonova, S.V., Mezenova, O. Ya., Baidalinova, L.S., Grimm, T. (2020). Study of deep processing of side meat and bone beef raw materials to obtain functional organic compositions. Vsyo o myase, 5S, 207-211. https://doi. org/10.21323/2071-2499-2020-5S-207-211 (In Russian)

14. Sviridenko, Yu. Ya., Myagkonosov, D.S., Abramov, D.V., Ovchinnikova, E.G. (2017). Theoretical and practical aspects of development technology of manufacturing protein hydrolyzates for spe- cial nutrition use. Part 1. Technology of production and technical characteristics of hydrolysates. Food industry, 5, 48-50. (In Russian).

15. Shchekotova, A.V., Khamagaeva, I.S., Tsyrenov, V. Zh., Darbakova, N.V., Khazagaeva, S.N. (2019). Biotechnological processing procedures of collagen-containing raw materials for creation of functional foods. Proceedings of universities. Applied chemistry and biotechnology, 9(2), 250-259. https://doi. org/10.21285/2227-2925-2019-9-2-250-259

16. Budaeva, A. E. Bazhenova, B.A., Danilov, A.M. (2015). Chemical modification of collagen containing raw materials for use in production of meat products. Vsyo o myase, 1, 31-35. (In Russian)

17. Lukin, A. (2020). Application and comparison of proteolytic enzyme preparations in technology of protein hydrolyzates. Food Science and Technology, 40, 287-292. https://doi.org/10.1590/ fst.09319

18. Li, S., Song, S., Xiao, Z., Niu,Y., Tang, Q., Fan, L. (2016). Influence of lipase pretreatment on beef bone protein hydrolysate. Journal of Chinese Institute of Food Science and Technology, 16(4), 130136. https://doi.org/10.16429/j.1009-7848.2016.04.018

19. Pagán, J., Ibarz, A., Falguera, V., Benítez, R. (2013). Enzymatic hydrolysis kinetics and nitrogen recovery in the protein hydrolysate production from pig bones. Journal of Food Engineering, 119(3), 655-659. https://doi.org/10.1016/j. jfoodeng.2013.06.040

20. Chiang, J. H., Loveday, S. M., Hardacre, A. K., Parker, M. E. (2019). Effects of enzymatic hydrolysis treatments on the physicochemical properties of beef bone extract using endo- and exoproteases. International Journal of Food Science and Technology, 54(1), 111-120. https://doi.org/10.1111/ijfs.13911

21. Mezenova, N. Yu., Agafonova, S.V., Mezenova, 0. Ya., Baydalinova, L.S., Volkov, V.V. (2020). The use of enzymatic modification in recycling of meat and bone collagen-containing byproducts. Proceedings of universities. Applied chemistry and biotechnology, 10(2(33)), 314-324. https://doi.org/10.21285/2227-29252020-10-2-314-324 (In Russian)

22. Wisuthiphaet, N., Kongruang, S., Chamcheun, C. (2015). Production of fish protein hydrolysates by acid and enzymatic hydrolysis. Journal of Medical and Bioengineering, 4(6), 466-470. https://doi.org/10.12720/jomb.4.6.466-470

23. Yao, Y., Wang, M., Liu, Y., Han, L., Liu, X. (2020). Insights into the improvement of the enzymatic hydrolysis of bovine bone protein using lipase pretreatment. Food Chemistry, 302, Article 125199 https://doi.org/10.1016/j.foodchem.2019.125199

24. Tutelyan, V.A., Khavinson, V. Kh., Ryzhak, G.A., Linkova, N.S. (2014). Short peptides as nutritional components: molecular basis of homeostasis regulation Uspehi sovremennoj biologii, 134(3), 227-235. (In Russian)

25. Grishin, D.V., Podobed, O.V., Gladilina, Yu.A., Pokrovskaya, M.V., Alexandrova, S.S., Pokrovsky V. S. et al. (2017). Bioactive proteins and peptides: current state and new trends of practical application in the food industry and feed production. Problems of nutrition, 86(3), 19-31. (In Russian)

26. Asyakina, L., Babich, O., Dolganuk, V., Suhih, S. (2016). Methods of production and purification of biologically active peptides. Research Journal of Pharmaceutical, Biological and Chemical Sciences, 7(4), 2415-2422.

27. Mora, L., Reig, M., Toldrá, F. (2014). Bioactive peptides generated from meat industry by-products. Food Research International, 65(PC), 344-349. https://doi.org/10.1016/j. foodres.2014.09.014 


\section{AUTHOR INFORMATION}

Natalya Yu. Mezenova - candidate of technical sciences, docent, Department of Food Biotechnology, Kaliningrad State Technical University. 236022, Kaliningrad, Sovetsky prospect, 1. Tel .: +7-4012-46-35-69, E-mail: nataliya.mezenova@klgtu.ru https://orcid.org/0000-0002-7433-7189

Svetlana V. Agafonova - candidate of technical sciences, docent, Department of Food Biotechnology, Kaliningrad State Technical University. 236022, Kaliningrad, Sovetsky prospect, 1. Tel .: +7-4012-46-35-69, E-mail: svetlana.agafonova@klgtu.ru https://orcid.org/0000-0002-5992-414X

Olga Ya. Mezenova - doctor of technical sciences, professor, Head of the Department of Food Biotechnology, Kaliningrad State Technical University. 236022, Kaliningrad, Sovetsky prospect, 1. Tel .: +7-4012-46-35-69, E-mail: mezenova@klgtu.ru https://orcid.org/0000-0002-4716-2571

* corresponding author

Larisa S. Baidalinova - candidate of technical sciences, docent, Professor, Department of Food Biotechnology, Kaliningrad State Technical University. 236022, Kaliningrad, Sovetsky prospect, 1. Tel .: +7-4012-46-35-69, E-mail: larisa.baydalinova@klgtu.ru https://orcid.org/0000-0002-4308-4326

Thomas Grimm - Biotechnology Engineer, Director, Biotechnology Firm ANiMOX, Max-Planck-Str. 3, 12489 Berlin. Tel.: +49-306-392-1041, E-Mail: t.grimm@animox.de https://orcid.org/0000-0003-4035-4447

All authors are responsible for the work and data presented.

All authors made an equal contribution to the work.

The authors were equally involved in writing the manuscript and are equally responsible for plagiarism.

The authors declare no conflict of interest.

Received 15.02.2021 Accepted in revised 19.03.2021 Accepted for publication 25.03.2021 